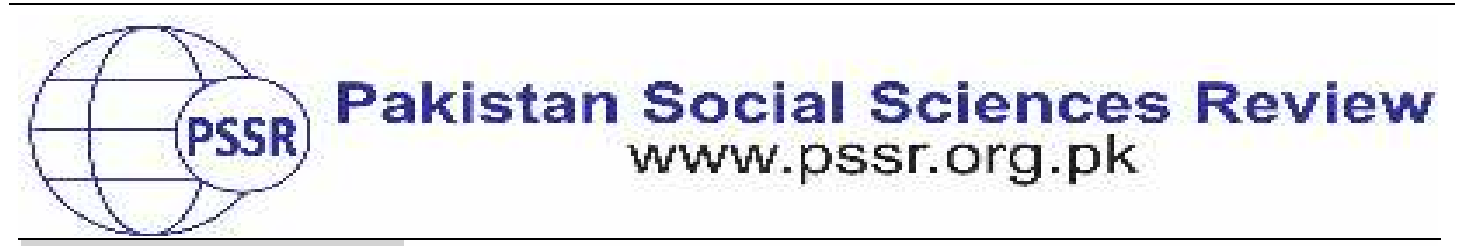

RESEARCH PAPER

\title{
Notion and Features of Orientalism in Historiography
}

\author{
Dr. Muhammad Shafiq*1 Dr. Muhammad Ikramullah Khan²
}

1. Assistant Professor, Department of History, The Islamia University of Bahawalpur, Punjab, Pakistan

2. Assistant Professor, Department of Pakistan Studies, The Islamia University of Bahawalpur, Punjab, Pakistan

\begin{tabular}{|c|c|}
\hline PAPER INFO & ABSTRACT \\
\hline $\begin{array}{l}\text { Received: } \\
\text { August 31, } 2021 \\
\text { Accepted: } \\
\text { December 29, } 2021 \\
\text { Online: } \\
\text { December 31, } 2021\end{array}$ & $\begin{array}{l}\text { Orientalism is a popular political, cultural and intellectual } \\
\text { perspective that is used in studying the history of people of the } \\
\text { East by the Western thinkers. The Europeans originated this } \\
\text { notion in colonial era, advanced in post-colonial period and } \\
\text { even now is frequently used by the Americans. The concept of }\end{array}$ \\
\hline $\begin{array}{l}\text { Keywords: } \\
\text { Colonial Era } \\
\text { Edward Said, } \\
\text { Historiography, } \\
\text { Knowledge, } \\
\text { Orientalism. }\end{array}$ & $\begin{array}{l}\text { orientalism is built on power and authority with respect to } \\
\text { knowledge. Based on their existing knowledge and by using } \\
\text { their own point of view, the western thinkers studied the } \\
\text { eastern civilizations like Islamic Arab world, African and Indian } \\
\text { societies and cultures under Muslim rule. Hence, orientalism }\end{array}$ \\
\hline $\begin{array}{l}\text { *Corresponding } \\
\text { Author } \\
\text { muhammad_shafi } \\
\text { q@iub.edu.pk }\end{array}$ & $\begin{array}{l}\text { the eastern cultures and civilizations were inferior to the } \\
\text { western cultures and civilizations. The paper attempts to } \\
\text { understand the definition and meaning of orientalism, its } \\
\text { growth as a system of knowledge in political, cultural and } \\
\text { intellectual fields. Furthermore, there is a great need to } \\
\text { understand that west has used the notion of orientalism in } \\
\text { enhancing its influence and interests in the east. In this respect, } \\
\text { Edward Said's idea of orientalism is examined in great detail. } \\
\text { The study analyses orientalists' method towards historiography } \\
\text { by describing features of orientalism. The research also sheds } \\
\text { light on criticism received by orientalism. The study concludes } \\
\text { that orientalists while writing history undermine progress of the } \\
\text { orient civilizations in general, and Islam in particular. }\end{array}$ \\
\hline
\end{tabular}

\section{Introduction}

The concept of "orientalism" is a known intellectual, political and cultural western viewpoint about the history of people of orient. This phenomenon was emerged as a product of intellectuals with reference to the power of knowledge in the course of colonial and post-colonial epoch (Al-Da'mi, 1998). Orientalism, states Edward W. Said, is "a political vision of reality whose structure promoted the difference between the familiar (Europe, the West, 'us') and the strange (the orient, 
the East, 'them')" (Said, 1978, 43). Orientalist historians compare European concepts of "God, man, nature, society, science, and history to Eastern civilizations, notably Islam, and conclude that non-Western cultures and civilizations are inferior and backward" (Said, 1978, 43). The Orientalists believed that Muslims were inferior to the West and that the West was superior. Furthermore, Muslim cultures were thought to be corrupt, whereas Western civilizations were thought to be clean. In this sense, colonialism was needed in order to civilise these populations and their systems.

Christianity and Judaism in the West felt endangered when Islam arrived in the seventh century. To counteract the effect of Islam, Christian missionaries began researching Islam, resulting in the formation of Orientalism as a school of thought. They adopted a biased perspective to Islam in light of historical hostility. Orientalists purposefully distorted even the character of the last Holy Prophet Hazrat Muhammad (peace be upon him) and the Qur'an as a divine book through their writings. They further claimed that in Makkah, Muhammad presented himself as a prophet, but in Medina, he appeared to be more like a politician. Even against the Ottoman Empire and Muslim rulers in the subcontinent, this attitude persisted. Orientalists served as agencies for their masters' cultural, economic and political preferences during the era of Colonialism. They portrayed Eastern empires, particularly Muslim and Indian cultures, as underdeveloped, while Western civilization, as evolved, which bears the burden of educating the Eastern civilization. Within that way, rationale for colonialism was provided. Orientalists have taken the same unfavourable view toward Islam and the Muslim world even today, particularly in the aftermath of the $9 / 11$ terrorist attacks.

\section{Material and Methods}

The desk research method is used to collect the data from primary and secondary resources. Facts and events are presented by using descriptive, analytical and qualitative type of research. Logic, reason and arguments are used while analyzing the data.

\section{Orientalism: Meaning and Definition}

It is necessary to understand the term Orientalism before studying Orientalists' perspective on historiography. It's worth noting that the name Orientalism derives from the Latin word 'orients', which means "rising sun" and refers to the "East" as opposed to the "Occident" or "West." It is a discipline of academia that employs typical Western methodologies to comprehend and gather information about the Orient. It explains the way the West looks at the Orient in order to understand it within the perspective of Western experience in a broad sense. Orientalism is a definitive approach to the Orient taken by Western historians in an 
attempt to build a common knowledge base about the region. The study of Eastern ideas, history, religion, culture, language, and social systems is included in this endeavor (Nooruddin).

\section{Growth of Orientalism}

John of Damascus (d.748), a Christian philosopher and close companion of Ummayad Caliph Yasid, set the foundations for Orientalism. He called Islam a barbarian religion, Makkah's Ka'aba an idol, and Muhammad a non-religious and lustful man. He said that an Arian monk taught Muhammad how to piece together his theology from the Old and New Testaments. John of Damascus' writings and charges became the standard source for all Biblical texts about Islam (Sardar, 2002, p.18).

Orientalism has always been essentially political, with cultural and intellectual aspects coming in second. It began in the late seventeenth century as a system of knowledge and reached its pinnacle in the late $19^{\text {th }}$ century and early $20^{\text {th }}$ century. During this time, Britain and France, and eventually the United States, were fighting for Western influence. This Anglo-French-American encounter was imperialistic in nature. As a result, inherent in the Orientalist mindset is the assumption that the Orient had passed its great period at the same time that the West was being 'born,' and was consequently in decay. This perception of the Orient as archaic and savage led to conclusions that more closely reflected what scholars wanted to think than what actually happened. In philosophy, this mentality led to the assumption that Muslim philosophy as a whole was derived from the Greek legacy; this, in turn, contributed to the opinion that Islamic intellectuals weren't really good People, as philosophy and religion appeared to be incompatible. Orientalism also had a key role in enhancing Western interests in the East, in addition to this mindset. The quest of Orient knowledge was not always a goal in and of itself. The study of Islamic philosophy only served to reinforce numerous Western experts' convictions about their own culture's greatness (Nooruddin).

\section{Edward Said and "Orientalism"}

Edward Said, a 20, century scholar, redefined the word Orientalism in his book 'Orientalism,' using it to define a prevalent Western tradition, both scholarly and artistic, of aggressive and depreciatory perspectives of the East, formed by European imperialism's behaviours in the eighteenth and nineteenth centuries. However, several modern researchers have coined the word to allude to Imperialistera authors who were pro-Eastern, rather than those who saw no merit in nonWestern traditions.

One of Edward Said's core ideas is that Western understanding of the East is 
based on predetermined stereotypes that see all "Eastern" nations as similar in many ways to each other and significantly different from "Western" society. This "a priori" understanding declares "the East" to be diametrically opposed to "the West". Literary writings and historical records are used to develop such Eastern knowledge, which frequently have a restricted grasp of the reality of living in the Middle East.

Said stressed the connection "between power and knowledge" in popular and academic discourse, particularly in regard to European perceptions of the Arab world of Islam, in line with Michel Foucault's concepts. According to Said, the terms Orient and Occident functioned as antagonistic words, with the "Orient" being produced as a negative reflection of Western society. Another thinker, Antonio Gramsci, had a significant influence on Edward Said's study in this field. Said's understanding of the universality of Orientalist constructions and images in Western research and reportage, and their link to the exercise of authority over the 'Orient', can be shown to have been inspired by Gramsci's theory of hegemony.

Despite the fact that Edward Said's debate was restricted to academic research of Middle Eastern, African, and Asian history and culture, he stated that "Orientalism is, and does not merely represent, a significant dimension of modern political and intellectual culture" (Said, 1978, p.53). Said's criticism of scholastic Orientalism is almost exclusively restricted to study from the late nineteenth and early twentieth centuries.

Said's publications have influenced analyses of imperialist Western attitudes toward India, China, and other countries, in addition to Middle East studies. It was an influential work in the field of postcolonial studies. In his book Culture and Imperialism, published in 1993, Said expanded and refined his theories. In the preface to Orientalism, Said offers numerous meanings of 'Orientalism'. Some of these have received greater attention and influence than others:-

a. "A way of coming to terms with the Orient that is based on the Orient's special place in European Western experience" (Said, 1978, p.1).

b. "a style of thought based upon an ontological and epistemological distinction made between 'the Orient' and (most of the time) 'the Occident'." (Said, 1978, p.2).

c. "A Western style for dominating, restructuring, and having authority over the Orient." (Said, 1978, p.3).

d. "...particularly valuable as a sign of European-Atlantic power over the Orient than it is as a veridic discourse about the Orient." (Said, 1978, p.6).

e. "A distribution of geopolitical awareness into aesthetic, scholarly, 
economic, sociological, historical, and philological texts." (Said, 1978, p.12).

\section{Historiography and Orientalists}

Orientalism was a scholarly tradition dealing with the development of Asian civilizations, the identification, editing, and interpretation of these civilizations' vital texts, and the distribution of this scholarly tradition from one generation to the next through a well-established chain of students and teachers. It was primarily on Islam and Islamic studies. Orientalism compares Islam and several other civilizations to European conceptions of Lord, human, nature, community, science, and history, concluding that non-Western traditions and civilizations are lower and inferior (Sardar, 2002, p.4).

It came to the Orient with distinct beliefs about cultural history, religion's beginnings and evolution, how sacred texts should be regarded and understood, political beliefs, and how human civilizations grow over time. The analysis of the politics of need by Orientalists is historiography that upholds western ambitions into academic disciplines and then translates such desires into its understanding of the Orient. It declared Islamic, Chinese, and Indian disciplines to be non-scientific; perpetuating the myth that true science was invented and owned by the West. Similarly, Islamic law wasn't really law in any significant way, Chinese medicine was not medicine in any meaningful sense, and Indian civilisation had no concept of logic; genuine reason was the exclusive domain of Western civilisation. The Orient has always lagged behind the West on the evolutionary scale. Scholarly Orientalism developed into a guarded establishment that has its own teaching, communication, and networking equipment, as well as a method for transferring the light from teacher to student. "Based on an ontological and epistemological divide between the West and the Orient, it developed its own style of thought and technique of analysis". It evolved into a self-sustaining and exclusive tradition that vigorously fought any internal and external critique; an authoritative structure that thrives today as much as it did during colonial period (Sardar, 2002, p.5).

Some of the famous Orienalists are John of Damascus, Karl August Wittfogel (Oriental Despotism), Sir William Jones, Samuel Johnson, William Beckford, Lord Byron, James Rennel, Francois Bernier, Sir William Temple, Charles Grant, James Mill, Christian Lassen, Walzer, Rosenthal, Eric Meyer, W. Cantweell Smith (Islam in the Modern World), H.A.R Gibb (Modern Trends in Islam), Philip. K Hitti (Islam and the West), Kenneth Craig, Norman Anderson, Patricia Crone (Hagarism: The Making of the Islamic World), William Wilson Hunter (Indian Mussalman), Stanley LanePoole, Michael Cook (Muhammad), Daniel Pipes (In the Path of God: Islam and Political Power), Francis Fukuyama (The End of History), Samuel Huntington (The Clash of Civilization) and Salman Rushdie (The Satanic Verses). 


\section{Characteristics of Orientalists' Historiography}

The following are some key features of Orientalist historiography:-

Orient's Adherence to Tradition: "Orientalist scholars believe that the West progresses and changes while the Orient remains unchanging in its adherence to tradition and hence remains backward and buried in medieval history" (Sardar, 2002, p.7). Orientalists had a particular stance on tradition. They exposed the Orient's history by presuming they had greater power and authority on it than the local inhabitants. Orientalists, for example, did not just study but also established Islamic law, which has a lengthy history and tradition. Muslims, according to Orientalists, are fundamentally conservatives who follow archaic traditions and rituals.

Despotic Muslim Rulers and Theocratic State in India: “Orientalists in India not only discovered the past, but also reconstructed it to suit their needs. They saw Muslims as foreigners who had controlled India for a long time as dictatorial rulers, while the natives, Hindus, had been oppressed by the intruders". A history was made up with a Hindu great era that ended in the era of Muslim incursions and tyranny. Orientalist historians have painted a picture of India in the $13^{\text {th }}$ and $14^{\text {th }}$ centuries as a theocratic kingdom ruled by dictatorial Muslim emperors. Orientalists such as V.A. Smith claimed that the Muslim sultans of the Delhi Sultanate were religious fundamentalists, racists, and radicals. Francois Bernier, a Mughal specialist who also served as a surgeon at the Mughal court, said that under Mughal rule, India, a bountiful country with a favourable trade balance, caused poverty and left territories uncultivated (Sardar, 2002, p.31). Orientalist historians maintained that authoritarianism arose from the lack of civil society institutions, lacking which it was impossible to break free from feudalism. For example, Muslim cultures lacked independent towns, logical bureaucracies, legal stability, an industrious bourgeois class, and the rights and freedoms that come with any constitutional and social tradition. As a result, there were no neutral organizations to arbitrate between citizens and the government. As a result, the individual was eternally subjected to the despot's arbitrary authority. Civil society's lack not only aided Oriental despotism, but also prevented Muslim states from developing economically. As a result, Islam's nature included feudalism, authoritarianism, and political repression. Turkish civilisation served as a paradigm for the rise of Oriental dictatorship. The Ottoman Empire, according to Sir William Temple, was the most powerful in the world. Instead of a hereditary aristocracy, the Sultan was a sole monarch supported by subordinate ministers (Sardar, 2002, p.31).

"India's Past was Static and Unchanging": Orientalists felt that Indian society was stagnant and unchangeable in the past. Indian civilisation has stayed largely intact from the advent of the Aryans to the coming of the British, according to James Mill. Hegel's idea of history was directly influenced by this notion of an 
everlasting nation. Historical truth, according to Hegel, entailed dialectic change and progress. As the German philosopher saw it, Indian civilisation stayed motionless and stable, and so beyond the flow of global history. Before the publishing of Sir William Jones' publications, a $18^{\text {th }}$ century British Orientalist, Indian history was known as "Indo-Muslim" history, but with Jones' move in historical investigation to prehistoric times, it became known as "Hindu History". As a result of Jones' efforts, the concept of a Hindu and Muslim India became entrenched in Indian history. In 1817, James Mills published The History of British India, which solidified the periodization into Hindu, Muslim, and British India (Anjum, 2005, p.43-44). Christian Lassen used the Hegelian dialectic to periodize Indian history, with the exception that the three phases of thesis, antithesis, and synthesis in his hands were Hindus, Muslims, and Christians, rather than the British, as in Mill's research. However, Lassen was unable to challenge Hegel's concept of unchanging nature in relation to India's past (Thapar, 1984, p.6-7). Despotism arose from the unchangeable Indian society, according to Orientalists. The unchangeable structure of the Indian village which was populated by people uninterested with political relationships was seen to constitute the foundation of Indian society. Oriental despotism, according to Orientalist historians, arose from a lack of concern for politics and what was thought to be a lack of privately owned property in land. As per Romila Thapar "The static character of Indian society with its related despotic rulers became an accepted truth of Indian history" (Thapar, 1984, p.6). It is thought that Karl Marx adopted the idea of India's past being unchangeable and incorporated it into his thesis of Asian system of production. The Asiatic Mode of Production was distinguished by its self-sufficient village economy and the lack of private land ownership. With the concept of India's unchanging character in mind, Orientalist intellectuals such as Henry Maine, Durkheim, Weber, Stephens, Strachey, Lyall, and Hunter saw British administration as a catalyst in transforming Indian culture and a proof for justification of British rule in India (Sreedharan, 2004, p.423).

Dominance of the Political Element: The prominence of the political factor was the most essential feature of Orientalist historiography on India. The authors were uninterested in Indian life and culture, and economic matters were only addressed in as much as they were politically relevant. Governor General Wellesley created the College of Fort William as a training institution in Calcutta in 1800, and for the next two and a half decades, it was the most excellent tool of British Orientalism in India. British officials' works tended to be limited to the British rule and focused solely on British operations. They consistently conveyed the viewpoint of the British. Short descriptions of Traditions and etiquette were included solely to highlight their richness and to underscore their decadence (Sreedharan, 2004, p.424).

Prejudice towards Islam: The bias of Orientalist historians to Islam is examined in the following sections:- 
(1) The basis for the development of Orientalism was laid by Christian missionaries. In truth, the missionary Orientalists had only one goal: to dispute and refute the Prophet's status as such, as well as the Qur'an's identity as revelation. To put it another way, they studied Islam not to understand it but to undermine it (Hussain, 1984, p.7).

(2) Orientalists have always had two perspectives on Islam. "First, Islam was thought to be a crude parody of Christianity since it borrowed heavily from Abrahamic (Judaeo-Christian) traditions. Second, Islam was viewed as an alien threat, with a long history of military and political success over the world, and hence posed a threat to Western civilization" (Nooruddin).

(3) Islam has to be brought inside the framework of Western knowledge with respect to Christian conceptions before being considered on its own terms in Orientalism. Making comparisons between Christian and Islamic religions was one way of achieving this. The apparent analogy is that between Muhammad and Christ, which some Orientalists draw. Because Christ is at the centre of the Christian faith, Westerners imagined Muhammad occupied the same position in Islam. This misunderstanding contributed to the widespread use of the word "Mohammedanism", which Muslims find derogatory. The Christ connection also used to support the idea that Muhammad was an 'impostor' and a weak imitation of the Christian Messiah (Nooruddin). "William Muir not only pondered the idea that Muhammad was inspired by the devil in his book Life of Mohamed, but he also embraced further scientific criticism, claiming that Muhammad's prophetic experiences were caused by epilepsy" (Ernst, 2003, p.22).

(4) In another way, Islam served as a provocation to the West. Islam offered a significant challenge to the Christian world from the time of the Arab victories in the $7^{\text {th }}$ century through the triumph of the Ottoman Empire. Islamic empires - Arab, Ottoman, or those in Spain and North Africa - had successfully opposed and conquered Christian Europe, at least for a while.

(5) Orientalists claim that Muhammad wrote the Qur'an himself. Farreaching historical, religious, literary, and linguistic conclusions can be inferred from this declaration, which are lifted to the dignity of facts through "endless repetition." To establish that Muhammad composed the Qur'an, Orientalists must show that in the first half of the $7^{\text {th }}$ century, a guy who couldn't read or write sat down in his desk to examine and cite prior authors for the production of the Qur'an. The Orientalists, however, proceed to identify the beginnings of Islam in the Judaeo-Christian past without providing this evidence (Sardar, 2002, p.57).

(6) Rather than employing their outstanding abilities to build a greater knowledge of the fusion and heritage that the Islamic philosophers have left, 
Orientalists like Walzer and Rosenthal spend a lot of time looking for flaws in the Islamic philosophical system. Walzer believed that all the Arab philosophers' work was 'stolen' from the Greeks, according to his book Greek into Arabic, published in 1962 (Nooruddin).

(7) The Orientalists' imagined divide between philosophy and religion has severely hampered appreciation of the contributions of Islamic philosophers. This attitude stems from the early resistance to the influence of Greek philosophy on Christianity. Orientalists believe the Muslims felt the same way about the tension between philosophy and religion as the early Christians. "There had been discussions between Islamic philosophers and theologians, but the attitude in the Arab and Islamic worlds was quite distinct than the Christian world; in the aforementioned, the philosophers were merely taking what they believed to be their valid heritage from the manuscript of human knowledge" (Nooruddin).

(8) Orientalists in modern academia utilised modernity as a benchmark for judging the Orient. And the Orientalists' arguments help to keep the spirit of Eurocentrism intact. The Orientalism's prejudice remains substantially unchanged, but the tone has softened and grown more courteous. The new argument, which is essentially the same as the previous, is that Islam is irreconcilable with the contemporary age; this assumption is supported by efforts to demonstrate Islam's inherent inadequacy to modernization. Smith and Hitti, for example, tried more openly to show that Islam was obsolete in the world today and that only secularism might save Muslims from a deep coma (Sardar, 2002, p.78-80).

\section{Criticism to Orientalism}

The following are some notable criticisms of Orientalist historiography:-

a. Orientalism is a subjective term, not an objective one. The 'Orient,' to be more precise, is whatever Orientalists claim it to be. It's a collection of abstractions based on Western concepts rather than Eastern realities. More than just a reflection of Greek concepts, Islamic philosophy has to be explored. It must be viewed as a branch of thinking that came into touch with a number of cultures and evolved into a separate and original type of philosophical thought as a result of these encounters, as well as a reflection on the Islamic sciences itself (Nooruddin).

b. Maryam Jameelah, a prominent Pakistani writer, evaluates the writings of six Orientalists in Islam and Orientalism and concludes that Orientalism isn't really a dispassionate, academic analysis of Islam and its civilization by the sophisticated faithful in the best tradition scholarship. Rather, it is a well-coordinated plot based on the social Darwinism, aimed at inciting our youngsters to rebel against their faith and dismiss the entire reputation of Islamic culture and history as 
irrelevant (Maryam, 1971, p.105).

c. Despite its intellectual advancements, modern Orientalism continues to depend heavily on the mediaeval image of Islam. It has merely rejected obsolete clothing in favour of more contemporary apparel. There are several examples of old notions persisting, not only in regard to the Qur'an and Muhammad, but also, logically, in regard to Islamic theology, law, and history.

d. Orientalist academia is devoid of rational thought, impartial standards, and fundamental civility, tolerance, and moderation when it comes to Muslim viewpoints. In the majority of cases, Orientalists' religious and political inclinations trump their scholarly judgments.

e. In the extensive work of Orientalist scholars on the origins of Islam, there is really no solid or convincing evidence that Islam stole from the Bible or Jewish scriptures. Orientalist claims are unproven broad generalisations in this sense, and Orientalist study is little more than a taught process of generating speculative discourses on the obvious.

f. The achievements of the East, as well as their contributions to science and education, were purposefully overlooked or hidden. They were regarded as having no or little value and were vilified as a result. This concept was used to explain the Orient's "backwardness" to its "fruitless past," with the purported unproductive quality of Oriental history projected as a particular constituent quality of Oriental reality. As a result, colonialism was declared guilt-free.

g. Indian and Muslim nationalist historiography arose in response to Orientalist historiography in quest of national identity and in opposition to imperialist attacks on Indian and Muslim society and civilizations.

While responding to a question that what is orientalists' approach towards historiography of Arab Muslim world and India, renowned Pakistani historian Dr. Aslam Syed said that one form of orientalism is that Indian Ocean or Arabian sea is seen as liquid continent and it is amazed that there is a difference between the attitude of those people who came India through land and the attitude of those who came India through sea. Liquid ways means that India is not connected by land to Europeans like British and French who established colonies here. It means that connection between India and Europeans was nothing but how they filled that gap. They have filled that gap by considering a distanced destiny to get something or to fulfill their interests but not to give them anything (Syed, 2021).

Dr. Aslam Syed added that next approach of orientalism is that one person who is sitting in London; will see the world from his perspective. So it is a location 
from where you look at the world. During colonial era British told subcontinent people not only directions (East, West, South, and North) but their location too. After Second World War the US told Indo-Pak people that how to look at the world? And our text books, our teachers, our syllabus makers all are inspired by the ideas of west (Syed, 2021).

According to Dr. Aslam Syed orientalists could never see east in true perspective as most of the orientalists were Christians and later on Jewish and amazing thing was that before $19^{\text {th }}$ century the Jewish world history perspective was totally different but when they needed protection and help of Britain and the US, their perspective was also changed. Dr. Aslam Syed added that orientalists' perspective was that Muslims invaded and ruined India whereas Europeans revived golden traditions of Hindu civilization. They had awakened Hindus up by writing text books for them which were taught in their universities and told them that who was your benefactor and who was not. Dr. Aslam Syed further said that unfortunately, this dictation or this lesson of orientalists still stayed in India and even very well practiced these days. The classic example of this is a book "the wonders of India" a very selective and very innovative idea in India that what Indians did during the time of their golden age (Syed, 2021).

\section{Conclusion}

The work produced through orientalism has provided a great deal of information on the Oriental world as a whole. In this context the contributions of $19^{\text {th }}$ and $20^{\text {th }}$ centuries' authors to our comprehension of overseas cultures and peoples are particularly noteworthy. However, various issues occur as a result of the attitudes and practices used in conventional Orientalist debate, which has had a severe influence on Western awareness. This has an impact on and undermines the way the West views the Orient in general, and Islam in particular. As noted by Edward Said orientalists fabricated a false image of east and considered it uncivilized with respect to civilized west. Furthermore, orientalists believed that Indian civilization remained static and unchanged due its adherence to the traditional society and self-sufficient in their basic needs. Meanwhile, orientalists also distorted the image of Islam and did not accept the fact that Islamic civilization made any scientific progress. According to them Muslim rulers in India were despotic and conservative and hence buried the glory of the Hindu civilization. So, it was the duty of the west to educate east and put them on the road of progress. In sum and substance, the discourse of orientalism is used as a tool and instrument of justification to start military campaigns or occupy the orient by the Europeans during colonial and post-colonial eras. The same perspective is used by the Americans after Second World War and in post 9/11 period by convincing to see the world through their lens of orientalism. Therefore, there is a great need to change this trend and present a neutral point of view while studying east. 


\section{References}

Al-Da'mi, Muhammed A. (1998) Orientalism and Arab-Islamic History: an Inquiry into the Orientalists' Motives and Compulsions. Arab Studies Quarterly. http//www.findarticles.com

Anjum, Tanvir. (2005) Temporal Divides: A Critical Review of the Major Schemes of Periodization in Indian History. Journal of Social Sciences, Government College University Faisalabad, 1 (1): 32-49

Breckenridge, Carol A. and Peter Van Der Veer. (Ed.). (1993). Orientalism and Postcolonial Predicament Perspective on South Asia.

Ernst, Carl W. (2003). Following Muhammad: Rethinking Islam in the Contemporary World. London: The Universty of North Carolina Press.

Hussain, Asaf. (1984). The Ideology of the Orientalism, In Robert Olson and Jamil Qureshi. (Ed.), Orientalism, Islam and Islamists. (pp.5-21). Vermont: Amana Books.

Nooruddin, Ubai. (2009). Orientalism and Islamic Philosophy. http://www.muslimphilosophy.com

Said, Edward W. (1978). Orientalism. London: Routledge and Kegan Paul.

Sardar, Ziauddin. (2002). Orientalism: Concepts in Social Sciences. New Delhi: Viva Books Private Limited.

Sreedharan, E. (2004). A Text Book of Historiography 500 BC to AD 2000. New Delhi: Orient Longman.

Syed, Aslam. (NIHCR) (2021, November, 27). Discourse of History: Indo-Pak History from Antiquity to Modernity IV: Indians and Arabs. https://www.youtube.com/watch?v=VUeUucogyCw

Thapar, Romila. (1984). Ancient Indian Social History: Some Interpretations. New Delhi: Orient Longman. 